fascinating record of the last 100 years as seen through the lens of the photographer. Not only the results, but also the intention behind the pictures are of great significance.

Of more specialized appeal is a volume recently issued by the Leica Works, the firm of Ernst Leitz in Wetzlar, to celebrate the one-hundredth anniversary of the firm. Erich Stenger, formerly professor of scientific photography at the Berlin Technische Hochschule, and one of the leading historians of photography-and there are not many in existence-is the author. He has presented a fascinating and picturesque account, well illustrated, of the various attempts to create a miniature camera. I do not know if the book will be commercially available. But information about this can undoubtedly be obtained by writing to the Ernst Leitz Works in Wetzlar.-Hellmut Lehmann-Haupt, School of Library Service, Columbia University.

\title{
The Analysis of Library Problems: Three Surveys
}

Report of a Survey of the Library of Stanford University for Stanford University, November 1946-March 1947. By Louis R. Wilson and Raynard C. Swank. (On behalf of the American Library Association.) Chicago. American Library Association, 1947. 222p. \$2.50. (Mimeographed)

Report of a Survey of the Libraries of the Alabama Polytechnic Institute, November 1948-March 1949. By Louis R. Wilson and Robert W. Orr. Auburn, Alabama Polytechnic Institute, 1949. 215p.

Report of a Survey of the Library of the University of New Hampshire, JanuaryFebruary, 1949. By Stephen A. McCarthy. [Ithaca, N.Y., 1949] 77p. (Hectographed)

Of surveys there appears to be no end. The three surveys listed above represent new additions to our survey literature, and extend the amount of detailed information that we have about three libraries: Stanford, Alabama Polytechnic Institute, and New Hampshire.

The Stanford survey was released by the American Library Association and Stanford University last year, although the report was made in 1947. Accompanying the report is a mimeographed letter to the Executive Secretary of the American Library Association from Dean Clarence $\mathrm{H}$. Faust, chairman of the Stanford Library Committee. The letter is significant because it indicates that some of the deficiencies that Drs. Wilson and Swank single out in the Stanford survey have already been corrected. "A job analysis has been conducted, a position classification has been developed, and reasonably adequate salary scales have been adopted. A number of new positions have been created, including an assistant directorship. Staff participation in library planning and administration has been encouraged with excellent results," writes Dean Faust.

Moreover, book funds have been increased, departmental allocations adjusted, relations between faculty and library more firmly established, acquisitional and accounting methods improved, cataloging speeded up, and serials procedures simplified.

For the most part, the Stanford survey follows the pattern of approach to library problems that has been so well established by Dean Wilson. All aspects of the Stanford Library are carefully considered, and specific recommendations made for improvement. The report is distinguished by its frankness and directness. Since Dr. Swank is now director of the Stanford libraries, he has the unusual responsibility of putting into effect the program designed by Dean Wilson and himself.

The contributions of Dean Wilson to American librarianship since his retirement as dean of the Graduate Library School of the University of Chicago have been so significant that one cannot help but take note of them. Surveyor of Stanford, Denver, Cornell, South Carolina and Alabama Polytechnic Institute, among others, he has written books, papers and reviews which have shown his keen insight into the problems of academic librarianship. As editor of the University of North Carolina Sesquicentennial Publications, a series of 18 volumes, he engineered a project of great magnitude. Those librarians who have had a chance to work with him on surveys also know of the contribution 
that he has made in developing their ability to analyze library problems.

In the survey of the libraries of the Alabama Polytechnic Institute, Dean Wilson and Mr. Orr provide a workable blueprint of library action for the future. The surveyors display a keen grasp of the numerous and varied problems of an expanding land-grant institution and suggest constructive solutions which should be understandable to the administration and library staff of A.P.I. The survey is also notable for its inclusion of up-to-date developments in library practice as applied to the A.P.I. situation. There appears to be no question that many of the land-grant college libraries have not fared too well in support, collections, buildings, personnel and organization. A number of the findings of Dean Wilson and Mr. Orr are similar to those gathered at the Virginia Polytechnic Institute libraries, which were surveyed recently by William $\mathrm{H}$. Jesse and your reviewer. ${ }^{1}$ The Wilson-Orr report should aid considerably in the understanding of land-grant college library problems. The aimlessness in some land-grant college library programs should not be allowed to continue.
It is perhaps worth noting that the A.P.I. survey is attractively printed, in addition to being well organized and well written. It can be used to advantage by librarians of other institutions, especially land-grant colleges, who are concerned with their library programs.

The New Hampshire survey by Dr. McCarthy considers detailed problems of government and administration, services, collections, personnel, budget and budget procedure, and building. Dr. McCarthy demonstrates that he has a clear recognition of the library problems at New Hampshire, and his recommendations for improving the services are moderate and thoughtful. One of the best statements this reviewer has seen on "The Place of the Library in the University" appears in Section IX. Although Dr. McCarthy does not employ the method of statistical comparison with other institutions, he uses standards wherever necessary in order to provide a basis for recommendations. The report should prove helpful to the New Hampshire administration in its solution of its library problems.-Maurice F. Tauber, Columbia University.

\section{L.C. Subject Headings}

Subject Headings Used in the Dictionary Catalogs of the Library of Congress. 5th ed. Edited by Nella Jane Martin. Washington, U.S. Government Printing Office, I 948 , viii, I 204p. $\$ 6.50$.

A completely new format which should enhance its efficiency and usefulness distinguishes the fifth edition of the Library of Congress subject list for which librarians have been waiting since mid-r947. Through the use of double columns on a larger page, suitable abbreviations, and a smaller, though easily legible type face, the subject heading list has been confined to a single volume. Although the resulting book is bulky, its eight pounds only exceeds the weight of the first volume of the fourth edition by one, and this edition is far more convenient to use.

1 Tauber, Maurice F. and Jesse, William H. Report of a Survey of the Libraries of the Virginia Polytechnic Institute, for the Virginia Polytechnic Institute, Janu. ary-May, 1949. Blacksburg, Virginia Polytechnic Institute, I949. I 2op.
By using boldface for main headings and lightface roman type for references and subdivisions (the latter formerly distinguished by italics) and by grouping all references to and from a heading under its single listing, the editor has contributed substantially to a saving in the user's time. The form to which librarians became accustomed in the H. W. Wilson supplements to the fourth edition has now been adopted with but little change for the main work. Similarly, by incorporating the rules for geographic subdivision in the preface, and by continuing to show specifications as to type of subdivision following each heading, the need for one auxiliary list ( $S u b$ ject Headings with Local Subdivisions. 5th ed. 1935) has now been erased for all but the occasional user. The resulting product is indeed an impressive example of a welldesigned and efficiently arranged library tool. Particularly noteworthy is its freedom from error, both in content and typography. A few 